\title{
3 Research Square

\section{Bioaccessibilities and health risk assessment of heavy metals in dust from the Guizhou-Guiyang urban zone, China}

\section{讴区}

Guizhou normal university

呕 ( $\sim$ wangji@gznu.edu.cn )

Guizhou normal university

赑

Guizhou normal university

购

Guizhou normal university

购

Guizhou normal university

购

Guizhou normal university

畈

Guizhou normal university

\section{Research Article}

Keywords: dust, heavy metal, bioaccessibility, health risk

Posted Date: September 3rd, 2021

DOl: https://doi.org/10.21203/rs.3.rs-868374/v1

License: (c) (1) This work is licensed under a Creative Commons Attribution 4.0 International License. Read Full License 


\title{
Bioaccessibilities and health risk assessment of heavy metals in dust from the Guizhou-Guiyang urban zone, China
}

\author{
Xin-Jie Yu ${ }^{\mathrm{a}}$, Ji Wanga*, Xiong-fei Cai ${ }^{\mathrm{a}}$, Shuai Zhang ${ }^{\mathrm{a}}$, Ding Li ${ }^{\mathrm{a}}$, Shuai- \\ $Z_{\text {hao }}$, Die $\mathrm{Xu}^{\mathrm{a}}$ \\ ${ }^{a}$ School of Geographic and Environmental Sciences, Guizhou Normal University, \\ Guizhou, China;
}

\begin{abstract}
To investigate the health risks of heavy metals in dust entering the human body from different exposure pathways. In this study, the old urban area of Guiyang was used as the study area to understand the heavy metals concentrations in surface dust, including recreational plazas, main streets, hospitals, residential areas, and schools in this city, and the bioaccessibility in the simulated lung phase and simulated gastrointestinal phase. The results showed that the concentrations of $\mathrm{Cu}, \mathrm{Pb}, \mathrm{Zn}, \mathrm{Cd}, \mathrm{Ni}$, and $\mathrm{Cr}$ in the dust were higher than the background values, especially the $\mathrm{Zn}$ content exceeded the background value by 9.71 times. The bioaccessibility results indicated that the most soluble heavy metals in the simulated lung phase, simulated gastric phase, and simulated intestinal phase were $\mathrm{Zn}, \mathrm{Ni}$, and $\mathrm{Cu}$, respectively, and the bioaccessibility of most heavy metals was significantly higher in the gastric phase than in the intestinal phase, and only $\mathrm{Cu}$ was higher in the intestinal phase than in the gastric phase. The linear results fit suggested that the total amount of heavy metals alone could not predict the human intake of heavy metals in the dust. Human health risk assessment based on bioaccessibility showed that children had higher non-carcinogenic and carcinogenic risks than adults for both hand-to-mouth ingestion and respiratory inhalation exposure pathways, but none of them exceeded the limit values.
\end{abstract}

Keywords: dust; heavy metal; bioaccessibility; health risk

\section{Introduction}

Cities are the most active areas for people nowadays, and the rapid development has also triggered a lot of environmental health problems at the same time (Li et al. 2019). As an inorganic pollutant, heavy metals have the characteristics for bioconcentration and difficult degradation and can cause a variety of hazards when they enter the human body through different exposure pathways (Tang et al. 2017). For example, although $\mathrm{Cu}$ is an important trace element for the human body, long-term exposure to $\mathrm{Cu}$ often causes damage to the human nervous system and blood circulation system (Damian et al. 2007). Pb will accumulate in the bone marrow and spleen after it enters the human body, it has the greatest impact on children, who will suffer 
irreversible damage to their intelligence after excessive exposure to $\mathrm{Pb}$, and in serious conditions will cause death (Balamuralikrishnan et al. 2020). $\mathrm{Zn}$, like $\mathrm{Cu}$, is also a common and essential trace element, but excessive intake of $\mathrm{Zn}$ will damage the human immune system (Till et al. 2018). Cd is a harmful element to the human body, although the content for $\mathrm{Cd}$ is very low in the natural environment. However, due to man-made reasons or special working conditions, a large amount of $\mathrm{Cd}$ ingested by the human body will be harmful to the respiratory tract and reproductive system, as well as to the bones (Kobra et al. 2021). Ni is also a trace element, but the body's demand for it is very small and once the body ingests a certain amount of $\mathrm{Ni}$, it can cause inflammation and even affect the body's genetic factors (Michael et al. 2021). Cr itself does not have biotoxicity, but the $\mathrm{Cr}$ entering the body will be converted into $\mathrm{Cr}^{6+}$, which is easily adsorbed on the mucous membrane surface for the respiratory tract and can cause various respiratory inflammatory diseases (Nancy et al. 2021).

Urban surface dust is a kind of solid particle deposited on artificial pavement and various buildings due to atmospheric deposition, and dust could act as an important vector for heavy metals and various kinds of pollutants, given that dust is at the different environmental interface and important source-sink effects (Renata et al. 2021). Therefore, many scholars have studied the sources and spatial distribution for heavy metals in dust, and most of the findings show that the sources for heavy metals in dust are mainly related to vehicle exhaust emissions, wear and tear for the vehicle itself and aging for pavement materials, while the spatial distribution is related to the source of pollution (Han et al. 2020; Yu et al. 2021; Jose et al, 2021). Due to heavy metals can be toxic to the human body, some scholars have also conducted health risk evaluations for heavy metals in the dust. However, the heavy metals in dust cannot be completely absorbed by the human body, and the health risk assessment based on total heavy metals may cause errors in the results, so some scholars have introduced bioaccessibility into the health risk assessment (Han et al. 2020; Expósito et al. 2021).

Bioaccessibility refers to the ratio of the number of contaminants released in the gastrointestinal fluid to the total amount after the contaminants in the matrix for soil and food enter the human digestive system, which represents the relative amount of contaminants absorbed by the human body (Yin et al. 2021). Compared with the traditional assessment methods, bioaccessibility can more accurately reflect the release of heavy metals in the human body, which is more scientific and reasonable. There have been a lot of researches on bioaccessibility at domestic and abroad, but the research objects mainly focus on soil heavy metals and metal mining areas, etc (Du et al. 2020; Sultana et al. 2020). Although the bioaccessibility of heavy metals in dust has been reported, the simulated digestion phase is only limited to the gastrointestinal phase, and the bioaccessibility of the simulated respiratory system in vitro is less reported. Human exposure to heavy metals is predominantly through two ways: inhalation and ingestion thus may cause various health problems (Khelifi et al. 2021). Therefore, in this study, we chose in vitro simulated human digestive system and respiratory system to conduct the bioaccessibility study, and it is significant to carry out a health risk assessment for urban populations based on bioaccessible concentration.

Guiyang (the capital city of Guizhou province) is one of the fastest-growing cities 
in southwest China, as well as an important regional innovation center and tourist city. With the rapid development of the economy and the continuous expansion of urban transportation, the problem of Guiyang's ecological environment has become increasingly prominent. Therefore, this study selected recreational squares, main streets, hospitals, residential areas, and schools in the old town of Guiyang, where crowds moving more widely, were used as a study area. The main objective of this study was to evaluate the total heavy metals concentrations for these locations. In vitro simulation method was used to simulate the leaching of heavy metals from dust in human lungs and gastrointestinal tract respectively, explore the bioaccessibility of heavy metals. Eventually, according to the bioavailability of heavy metals in different stages, the noncarcinogenic and carcinogenic health risk assessment of heavy metals for the population via different exposure pathways in the urban area was carried out respectively. The results of this study could provide accurate assessment for the population in this urban area, which can serve as a reference for pollution control and environmental planning for heavy metals in urban dust.

\section{Materials and methods}

\section{Study area}

Guiyang $\left(106^{\circ} 07^{\prime}-107^{\circ} 17^{\prime} \mathrm{N}, \quad 26^{\circ} 11^{\prime}-27^{\circ} 22^{\prime} \mathrm{E}\right)$, as it is known in Figure 1, is located in the central part of the Guizhou province, and the Yungui Plateau to the east, mainly dominated by hilly terrain and mountainous terrain. The altitude of the study area ranges from around $1100 \mathrm{~m}$, with a humid and mild subtropical climate, average annual temperatures of $15.3^{\circ} \mathrm{C}$, average annual relative humidity of $77 \%$, and annual sunshine time is about $1278 \mathrm{~h}$, owning annual precipitation of $1200 \mathrm{~mm}$ and a frost-free period of 270 days. The old urban areas of Guiyang City were selected for this research: Yunyan District and Nanming District, Yunyan District is located in the northern part of Guiyang City, with an area of $67.5 \mathrm{~km}^{2}$, Nanming District is located in the southern part of Guiyang City, with an area of $89.68 \mathrm{~km}^{2}$. The old urban areas have a longer development time, and there have been historical residues for heavy metals in the dust on the surface of old urban areas due to the expansion of traffic and the construction of a large number of high-rise buildings during the development process for many years. Therefore, people living in old urban cities are exposed to potential health risks from heavy metals in the dust. 


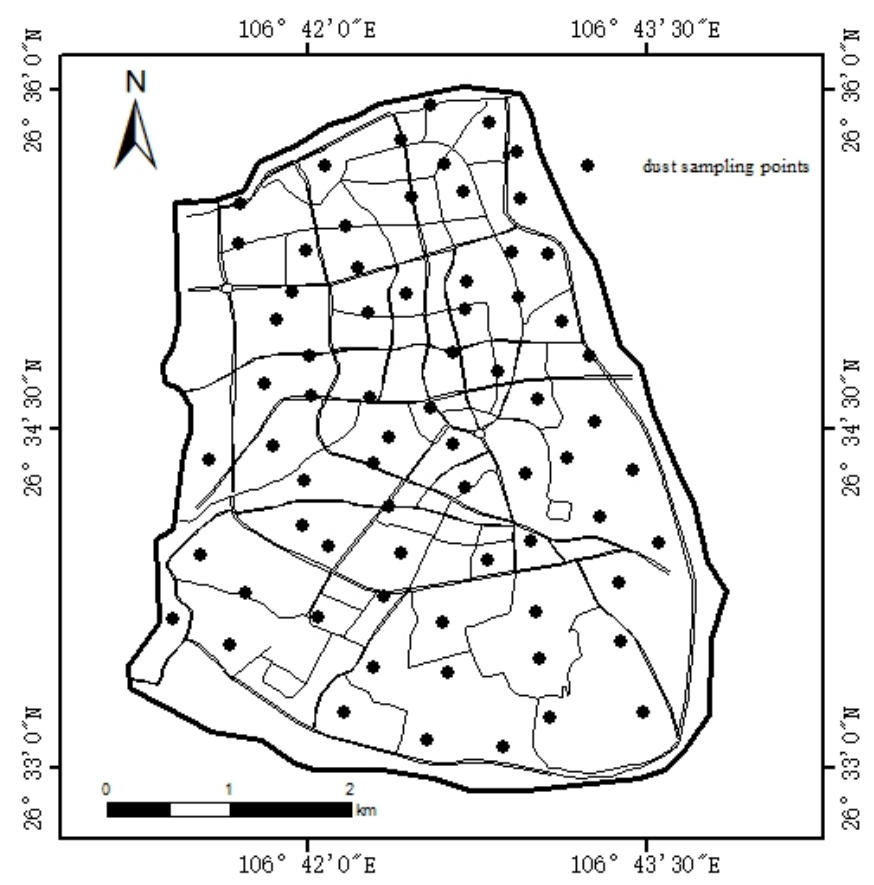

Figure 1. Sampling points and map of the study area

\section{Sampling and sample preparation}

A total of 71 dust samples were shown in Figure 1. The sampling sites covered recreational squares, main streets, hospitals, residential areas, schools, and other areas where people mainly concentrated of Yunyan District and Nanming District respectively. The dust samples are collected from April to May in 2021, and it was ensured that the humidity in the city was not high and the weather was clear during the sample collection period. April-May is the flowering period of major flowers in Guiyang, such as Rhododendron and orchids. To avoid large amounts of pollen in the dust, samples were collected mainly from the entrance for schools, air conditioning fans surface, windowsills for residential areas, main streets, and steps, and each dust sample was carefully collected by brush and dustpan and sampling tools were cleaned in sampling sites to avoid cross-contamination. All dust samples were packed in individually labeled polyethylene, sealed plastic bags, and transported back to the laboratory for processing after sampling was completed. Before the experiment, extra materials, such as hairs, sand, grit, and plant residues, were removed from samples through a $1 \mathrm{~mm}$ nylon screen. Then all samples were dried in an oven at $40^{\circ} \mathrm{C}$ until constant weight. Finally, samples were sieved through a $200 \mu \mathrm{m}$ mesh nylon screen, labeled, and prepared to be tested.

\section{Gamble analysis}

In vitro simulated respiratory system is mainly used Gamble analysis method, the method is Zoitos et al. (Zoitos et al.1997) combined with previous research, the proposed method showed qualitatively good correlation with in vivo results, after continuous validation studies, Gamble analysis has become a widely accepted approach for in vitro simulated respiratory system. The simulated lung fluid per liter contained 
$0.095 \mathrm{~g} \mathrm{MgCl}_{2}$ (Chengdu Jinshan Chemical Reagent Co.), 6.019 g NaCl (Chengdu Jinshan Chemical Reagent Co.), 0.298 g KCl (Tianjin Youpu Chemical Reagent Co.), $0.126 \mathrm{~g} \mathrm{Na}_{2} \mathrm{HPO}_{4}$ (Tianjin Kermel Chemical Reagent Co.), $0.063 \mathrm{~g} \mathrm{Na}_{2} \mathrm{SO}_{4}$ (Tianjin Kermel Chemical Reagent Co.), $0.368 \mathrm{~g} \mathrm{CaCl}_{2}$ (Tianjin Kermel Chemical Reagent Co.), $0.574 \mathrm{~g} \mathrm{CH}_{3} \mathrm{COONa}$ (Tianjin Kermel Chemical Reagent Co.), $2.604 \mathrm{~g} \mathrm{NaHCO}_{3}$ (Tianjin Kermel Chemical Reagent Co.), $0.067 \mathrm{~g} \mathrm{C}_{6} \mathrm{H}_{5} \mathrm{Na}_{3} \mathrm{O}_{7}$ (Tianjin Kermel Chemical Reagent Co.), and the final $\mathrm{pH}$ for the simulated fluid was adjusted to 7.4. Each reactor was set at 1:1000 solid-to-liquid ratio, experimental temperature simulated normal human temperature at $37^{\circ} \mathrm{C}$, it was shaken in a constant-temperature oscillator at 100 $\mathrm{r} \cdot \mathrm{min}^{-1}$ for $24 \mathrm{~h}$, the samples were centrifuged at $5000 \mathrm{r} \cdot \mathrm{min}^{-1}$ for $10 \mathrm{~min}$, and filtered through a $0.45 \mu \mathrm{m}$ filter membrane. Finally, the contents of $\mathrm{Cu}, \mathrm{Pb}, \mathrm{Zn}, \mathrm{Cd}, \mathrm{Ni}$, and $\mathrm{Cr}$ in the filtrate were measured by inductively coupled plasma mass spectrometry (ICPMS, PerkinElmer NexION 2000).

\section{Physiologically-based extraction test (PBET) analysis}

PBET analytical methods, it had become the most popular method in vitro for simulating the digestive system since it was proposed by Ruby et al. (Ruby et al 1993)in 1993 to determine the bioaccessibility for $\mathrm{Pb}$ and $\mathrm{Cd}$ in soil, which is based on human physiological characteristics simulating the gastric digestion and intestine absorption phases to determine the bioaccessibility for different heavy metals in the matrix, and Ruby et al. (Ruby et al.1999) also found that the results obtained from the in vitro simulation method showing good correlation when the results were compared with the animal experiments. This analysis method was divided into two phases, and the simulated gastric juice contained $0.5 \mathrm{~g}$ sodium malate (Shanghai Aladdin Chemical Reagent Co.), 0.5 g sodium citrate (Shanghai Aladdin Chemical Reagent Co.), $0.42 \mathrm{~mL}$ lactic acid (Shanghai Aladdin Chemical Reagent Co.), $0.5 \mathrm{~mL}$ glacial acetic acid (Shanghai Aladdin Chemical Reagent Co.), and $1.25 \mathrm{~g}$ pepsin (Shanghai Aladdin Chemical Reagent Co.). The $\mathrm{pH}$ was adjusted consistently to 1.5 with $1 \mathrm{~mol} / \mathrm{L} \mathrm{HCl}$ (Chengdu Jinshan Chemical Reagent Co.). The simulated gastric juice was added to each reactor at a 1: 100 solid-to-liquid ratio, it was shaken in a constant-temperature oscillator at $100 \mathrm{r} \cdot \mathrm{min}^{-1}$ for $1 \mathrm{~h}$. Argon was injected into the simulated liquid at $1 \mathrm{~L} / \mathrm{min}$ for serving as an anaerobic environment. After $1 \mathrm{~h}$ for oscillation, the supernatant 30 $\mathrm{mL}$ was extracted and filtered through a $0.45 \mu \mathrm{m}$ filter membrane for analysis. In the intestinal phase, saturated $\mathrm{NaHCO}_{3}$ (Tianjin Kermel Chemical Reagent Co.) solution was added until the $\mathrm{pH}$ of the solution was 8.0, and then $0.14 \mathrm{~g}$ of bile salt (Shanghai Bowei Bio-Technology Co.) and $0.04 \mathrm{~g}$ trypsin (Shanghai Aladdin Chemical Reagent Co.) were added into the constant, and the shaking was continued under the same conditions as the simulated stomach for $4 \mathrm{~h}$. Then the supernatant was collected, centrifuged, and filtered. Gastric and intestinal extracts were stored at $4^{\circ} \mathrm{C}$ until assayed. Bioaccessibility in the gastric or intestinal stages could be calculated in the following form:

$$
B A C(\%)=\frac{C_{I V} \times V_{I V}}{T_{S} \times M_{S}} \times 100 \%
$$


where is the bioaccessibility for heavy metals; is the concentration for heavy metals in the soluble state in the lung dissolution, gastric digestion, and intestinal absorption phases for the simulated experiment $(\mathrm{mg} / \mathrm{L})$; is the volume for the reaction solution in each reactor $(\mathrm{L})$; is the total amount for heavy metals in the sample $(\mathrm{mg} / \mathrm{kg})$; is the mass for the sample in the reactor $(\mathrm{kg})$.

\section{Human health risk assessment}

Health risk assessment is a characterization method for potential threats to the human body due to exposure to toxic or harmful substances. In this research, the health risk assessment model developed by USEPA (USEPA 1989; USEPA 2001) was adopted for the assessment, for which they considered that contamination enters the human body mainly through the following three pathways: (1) direct hand-to-mouth unconscious ingestion for matrix particles; (2) inhalation for suspended particles through the respiratory tract; and (3) entering into the human body through skin contact. Considering that human exposure to heavy metals in the dust is mainly through the two exposure routes for respiratory inhalation and hand-to-mouth ingestion, this study was mainly based on simulated lung and simulated gastrointestinal bioaccessibility to calculate the average daily exposure and the corresponding noncarcinogenic and carcinogenic risks for adults and children under these two routes, and the average daily exposure (ADD) and risk values were mainly calculated in the following form:

$$
\begin{gathered}
A D D_{\text {inh }}=\frac{C_{\text {dust }} \times \operatorname{Inh} R \times E F \times E D}{P E F \times B W \times A T} \\
A D D_{\text {ing }}=\frac{C_{\text {dust }} \times \operatorname{Ing} R \times E F \times E D \times C F}{B W \times A T}
\end{gathered}
$$

The physical meaning and values of the specific formula parameters are listed in Table 1 .

\begin{tabular}{|c|c|c|c|c|c|}
\hline Parameter & Physical meaning & Unit & Child & Adult & Reference \\
\hline$C_{\text {dust }}$ & $\begin{array}{c}\text { The concentration of heavy } \\
\text { metals in dust }\end{array}$ & $\mathrm{mg} \cdot \mathrm{kg}^{-1}$ & - & - & This study \\
\hline $\operatorname{Ing} R$ & Daily intake rate & $\mathrm{mg} \cdot \mathrm{kg}^{-1}$ & 100 & 200 & USEPA(2008) \\
\hline $\operatorname{Inh} R$ & Inhalation rate & $\mathrm{m}^{3} \cdot \mathrm{d}^{-1}$ & 5.6 & 16.5 & USEPA(2008) \\
\hline$E F$ & Exposure frequency & day'year & 180 & 180 & USEPA(2008) \\
\hline$E D$ & Exposure time & year & 6 & 24 & USEPA(2008) \\
\hline$P E F$ & Dust emission factor & $\mathrm{m}^{3} \cdot \mathrm{kg}^{-1}$ & \multicolumn{2}{|c|}{$1.36 \times 10^{9} \mathrm{~m}^{3} \cdot \mathrm{kg}^{-1}$} & USEPA(2008) \\
\hline$C F$ & Conversion factor & / & \multicolumn{2}{|c|}{$1 \times 10^{-6}$} & USEPA(2008) \\
\hline$B W$ & Average weight & $\mathrm{kg}$ & 14.9 & 58.6 & Duan et al. 2012 \\
\hline$A B S$ & Skin absorption factor & l & \multicolumn{2}{|c|}{0.001} & USEPA(2008) \\
\hline$S A$ & Exposed skin surface area & $\mathrm{cm}^{2}$ & 4350 & 1600 & Duan et al. 2012 \\
\hline$A F$ & Average exposure time & l & 0.2 & 0.2 & USEPA(2008) \\
\hline $\begin{array}{c}A T \text { (non- } \\
\text { carcinogens) }\end{array}$ & Average exposure time & day & $365 \times 6$ & $365 \times 24$ & USEPA(2008) \\
\hline$A T$ & Average exposure time & day & $365 \times 70$ & $365 \times 70$ & USEPA(2008) \\
\hline
\end{tabular}

Table 1 Parameter values in average daily intake calculation models of heavy metals 
(carcinogens)

heavy metals accumulate in the human body under different exposure pathways and cause chronic non-carcinogenic risks, while $\mathrm{Cd}, \mathrm{Ni}$, and $\mathrm{Cr}$ are the main elements that cause cancer in people. The human health risks caused by respiratory inhalation, handoral ingestion, and dermal exposure in this study are expressed as HI and CR, respectively (USEPA, 2007).

$$
\begin{gathered}
H Q=\frac{A D D}{R f D} \\
H I=\sum H Q_{i} \\
C R=\sum A D D_{i} \times S F_{i}
\end{gathered}
$$

where HQ (Hazard Quotient) is the single non-carcinogenic risk; RfD is the reference dose at different pathways $\left(\mathrm{mg} \cdot \mathrm{kg}^{-1} \cdot \mathrm{d}^{-1}\right)$. HI represents the total non-carcinogenic risk due to all heavy metals; CR (Cancer Risk) represents the total carcinogenic risk due to all heavy metals; SF is the slope for carcinogenicity $\left(\mathrm{mg} \cdot \mathrm{kg}^{-1} \cdot \mathrm{d}^{-1}\right)$.

The Environmental Protection Agency (EPA) considers the risk to be low when HQ or $\mathrm{HI}<1$ and some non-carcinogenic risk when HQ or $\mathrm{HI}>1$; the carcinogenic risk is negligible when CR is below $10^{-6}$, within the acceptable range when it is between $10^{-6}$ and $10^{-4}$, and above $10^{-4}$, it is considered a serious carcinogenic risk. The physical meaning and values of the specific formula parameters are listed in Table

Table 2 Reference doses for non-cancer metals and slope factors for carcinogens

\begin{tabular}{cccccc}
\multicolumn{7}{c}{ metals } \\
\hline Elements & $R f D_{\text {ing }}$ & $R f D_{\text {inh }}$ & $S F_{\text {ing }}$ & $S F_{\text {inh }}$ & Reference \\
\hline $\mathrm{Cu}$ & $4.00 \mathrm{E}-02$ & $4.00 \mathrm{E}-02$ & - & - & USEPA(2008) \\
$\mathrm{Pb}$ & $3.50 \mathrm{E}-03$ & $3.50 \mathrm{E}-03$ & - & - & USEPA(2008) \\
$\mathrm{Zn}$ & 0.3 & 0.3 & - & - & USEPA(2008) \\
$\mathrm{Cd}$ & $1.00 \mathrm{E}-03$ & $1.00 \mathrm{E}-03$ & 6.1 & 6.30 & USEPA(2008) \\
$\mathrm{Ni}$ & $2.00 \mathrm{E}-02$ & $2.06 \mathrm{E}-02$ & - & 0.84 & USEPA(2008) \\
$\mathrm{Cr}$ & $3.00 \mathrm{E}-03$ & $2.86 \mathrm{E}-05$ & - & 42.0 & USEPA(2008) \\
\hline
\end{tabular}

\section{Sample analysis and data analysis}

In this study, dust samples were digested by $\mathrm{HCl}-\mathrm{HNO}_{3}-\mathrm{HF}-\mathrm{HClO}_{4}$ fouracid digestion method as detailed in the literature (Xiao et al. 2019), and heavy metals such as $\mathrm{Cu}, \mathrm{Pb}, \mathrm{Zn}, \mathrm{Cd}, \mathrm{Ni}$, and $\mathrm{Cr}$ were followed by analysis with an inductively coupled plasma mass spectrometer (ICP-MS), and all experimental samples were set as three parallel samples and reagent blanks were added throughout the experiment. The data were compiled by Excel 2016, the spatial distribution for sampling points was performed by ArcGis 10.2. For visualization of the data, results were plotted for using the OrginPro 8.0 program, the fit for the total dust heavy metals to the bioaccessible amount in different simulation phases was performed by SPSS 16.0, and the degree of the fit could reflect the correlation between total amount and bioaccessible amount.

\section{Results and discussion}




\section{Total metal concentration}

The concentration of $\mathrm{Cu}, \mathrm{Pb}, \mathrm{Zn}, \mathrm{Cd}, \mathrm{Ni}$, and $\mathrm{Cr}$ in 71 dust samples in this study were shown in Figure 2 and Table 3, which including minimum, maximum, median, mean, standard deviation, coefficient of variation (C.V), background values, and limited levels. From Table 3, all heavy metals concentrations of dust were significantly above the background values, which were 5.16, 1.82, 9.71, 2.92, 3.41, 4.99, and 1.72 times of the background value, respectively. The concentrations were as follows: $\mathrm{Zn}>\mathrm{Cu}>\mathrm{Cr}>$ $\mathrm{Ni}>\mathrm{Pb}>\mathrm{Cd}$, except for $\mathrm{Pb}$, other heavy metals were higher than limited levels. Although the concentration of $\mathrm{Pb}$ in this study exceeded the background value, it was significantly reduced compared with previous studies about heavy metals in urban road dust, so it could be inferred that the $\mathrm{Pb}$ concentration in this study was less than limited levels probably because of the widespread use of unleaded gasoline, while it was higher than background value probably due to the longer developmental history of old urban areas, and some of the $\mathrm{Pb}$ was deposited in the dust may be related to the wear and tear of automobile materials (Zheng et al. 2020). Among the investigated heavy metals, Zn content exceeded the standard significantly more than other heavy metals, and according to our analysis, the main sampling sites in this study were located near the main roads and near the parking lots of residential areas, while some studies suggested that the high concentration of $\mathrm{Zn}$ was related to the wear and tear for car parts and tires (Goix et al. 2016). According to the statistical principle, the larger the coefficient of variation $(\mathrm{C} . \mathrm{V})$, the greater the degree of dispersion of the pollutant, and the greater the influence of external factors. From Table 3, it could be seen that the coefficient of variation was ranked from high to low as $\mathrm{Pb}>\mathrm{Cd}>\mathrm{Zn}>\mathrm{Cr}>\mathrm{Cu}>\mathrm{Ni}$ so that it could be seen that $\mathrm{Pb}, \mathrm{Cd}$, and $\mathrm{Zn}$ showed a higher level of variation, indicating that these three heavy metals were more spatially distinct from $\mathrm{Cr}, \mathrm{Cu}$, and $\mathrm{Ni}$ are not uniformly distributed spatially compared with each other and were more influenced by external factors, while these conclusions in this study were also basically consistent with the results drawn by Fan et al (Fan et al. 2020).

Table 3 Concentrations of heavy metals $(\mathrm{mg} / \mathrm{kg})$ in surface dust.

\begin{tabular}{cccccccc}
\hline Element & Minimum & Maximum & Median & Mean \pm SD & C.V(\%) & $\begin{array}{c}\text { Background } \\
\text { value }\end{array}$ & $\begin{array}{c}\text { Limited } \\
\text { levels }\end{array}$ \\
\hline $\mathrm{Cu}$ & 100.67 & 315.72 & 156.98 & $165.41 \pm 47.37$ & 28.64 & 32.0 & 100 \\
$\mathrm{~Pb}$ & 11.24 & 163.34 & 45.82 & $64.41 \pm 44.28$ & 68.76 & 35.2 & 120 \\
$\mathrm{Zn}$ & 157.44 & 1793.91 & 996.21 & $966.61 \pm 373.19$ & 38.61 & 99.5 & 250 \\
$\mathrm{Cd}$ & 0.13 & 3.62 & 1.99 & $1.924 \pm 0.89$ & 46.41 & 0.659 & 0.3 \\
$\mathrm{Ni}$ & 73.72 & 187.52 & 127.82 & $133.26 \pm 26.39$ & 19.81 & 39.1 & 100 \\
$\mathrm{Cr}$ & 54.91 & 325.86 & 162.64 & $164.86 \pm 53.69$ & 32.57 & 95.9 & 200 \\
\hline
\end{tabular}



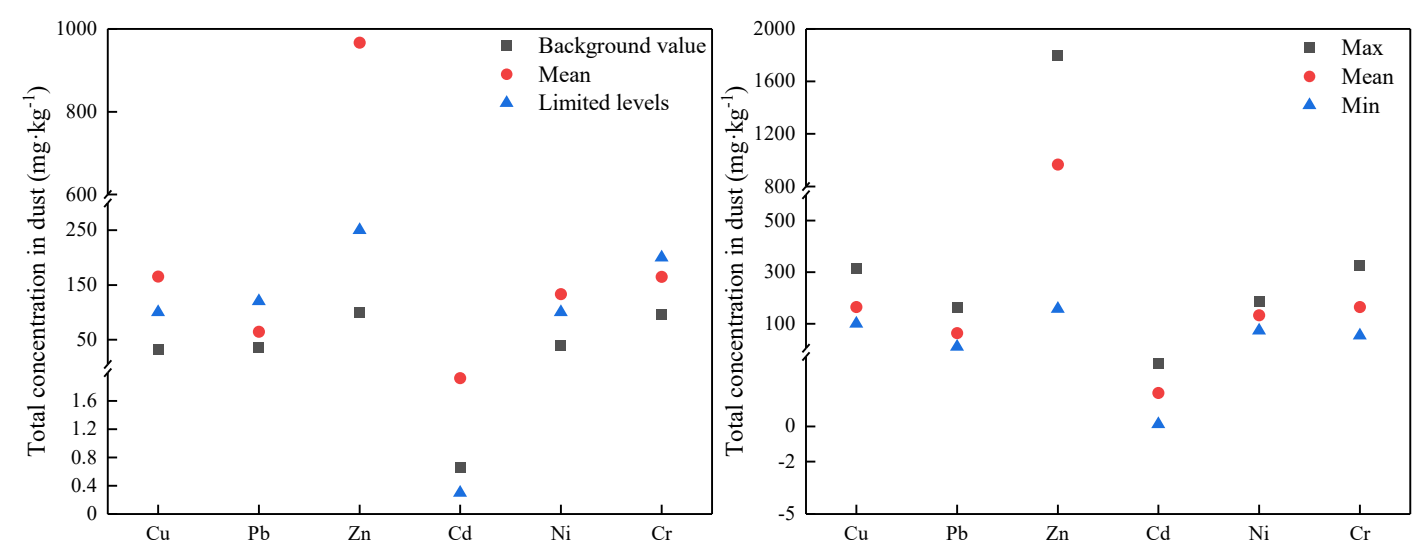

Figure 2. Total heavy metals in dust for this study

\section{In vitro stimulation of the respiratory system}

The bioaccessibility of $\mathrm{Cu}, \mathrm{Pb}, \mathrm{Zn}, \mathrm{Cd}, \mathrm{Ni}$, and $\mathrm{Cr}$ in the simulated lung was shown in Figure 3 and Table 4. Among the six elements involved in this study, $\mathrm{Cr}$ had the lowest bioaccessibility (3.81\%) and $\mathrm{Zn}$ had the highest bioaccessibility (38.97\%). It was possible that such a high solubility of $\mathrm{Zn}$ in the simulated lung may be related to the speciation characteristic of $\mathrm{Zn}$, which had been proved to be an important source of $\mathrm{Zn}$ in dust mainly in the form of $\mathrm{ZnO}$ (Adachi et al. 2004), while the low bioaccessibility of $\mathrm{Cr}$ may also be related to the speciation characteristic. Some researchers had extracted different forms of $\mathrm{Cr}$ by Tessier sequential extraction method and found that $\mathrm{Cr}$ was mainly in the insoluble residual fraction and the soluble fraction was relatively low, thus the bioaccessibility of $\mathrm{Cr}$ in simulated lung fluid was the smallest. In this study, the bioaccessibility of $\mathrm{Cd}$ in simulated lung fluid was similar to that of $\mathrm{Cr}$ and showed a lower level ( $\mathrm{Li}$ et al. 2019). In this study, the bioaccessibility of $\mathrm{Cd}$ in simulated lung fluid was similar to that of $\mathrm{Cr}$ and showed a lower level. However, some studies had shown that the bioaccessibility of $\mathrm{Cd}$ in simulated lung showed a higher level, and the reason for the difference may be related to the components in the simulated lung fluid, $\mathrm{pH}$, extraction time, and the source of Cd (Zhang et al. 2019). The bioaccessibility percentages of the other three heavy metals $\mathrm{Cu}, \mathrm{Pb}, \mathrm{Ni}$ in the simulated lung were $12.99 \%, 15.51 \%, 10.54 \%$, respectively.

\section{In vitro stimulation of the digestive system}

The bioaccessibilities of heavy metals in the dust for this study in the simulated gastric and intestinal phases were presented in Figure 3 and Table 4. In the Figure and Table, it could be seen that the bioaccessibility of $\mathrm{Cu}, \mathrm{Pb}, \mathrm{Zn}, \mathrm{Cd}, \mathrm{Ni}$, and $\mathrm{Cr}$ in the stomach and intestine of 71 sample points and an overview of the range, mean, concentration, and median bioaccessibility of heavy metals in dust samples were summarized in Table 2. The heavy metals with high bioaccessibility in the gastric phase were $\mathrm{Cu}, \mathrm{Zn}, \mathrm{Cd}$, and $\mathrm{Ni}$, which all reached more than $40 \%$, while $\mathrm{Cr}$ had the lowest dissolution rate of $4.19 \%$. In the intestinal phase, the average of heavy metals bioaccessibilities was as follows: $\mathrm{Cu}>\mathrm{Zn}>\mathrm{Ni}>\mathrm{Cd}>\mathrm{Pb}>\mathrm{Cr}$. Compared with the bioaccessibility of the gastric phase, the bioaccessibility in the intestinal phase was significantly lower, $\mathrm{Pb}$ bioaccessibility decreased from $23.89 \%$ to $13.26 \%$, Zn bioaccessibility from $45.22 \%$ to 
$26.49 \%$, Cd bioaccessibility from $43.07 \%$ to $20.17 \%$, and Ni from $46.16 \%$ to $25.32 \%$, $\mathrm{Cr}$ bioaccessibility did not change much from gastric phase to intestinal phase, while $\mathrm{Cu}$ bioaccessibility increased from $41.85 \%$ to $53.62 \%$. Overall, the bioaccessibility of most heavy metals was significantly higher in the gastric stage than in the intestinal stage, and some researches showed that heavy metals such as $\mathrm{Pb}, \mathrm{Zn}, \mathrm{Cd}$, and $\mathrm{Ni}$ were more active and easily soluble and digested under acidic conditions in the stomach (Soltani et al. 2021; Zhao et al. 2020), but heavy metals soluble in the gastric stage (acidic) would undergo adsorption- precipitation reactions when they entered the intestinal stage (alkaline) leading to a decrease in heavy metals solubility, while the small degree of change in $\mathrm{Cr}$ might be mainly attributed to the $\mathrm{Cr}$ was in the form of residue and the dissolution rate was not high in simulated human gastrointestinal fluid (Xing et al. 2019). The reason for $\mathrm{Cu}$ bioaccessibility increased was that $\mathrm{Cu}$ could complex with trypsin and bile salts, thus showed a higher solubility effect in the intestinal absorption phase (Xu et al. 2018).

Table 4 Bioaccessibility of heavy metals in the lung phase, gastric phase, and intestinal phase of dust.

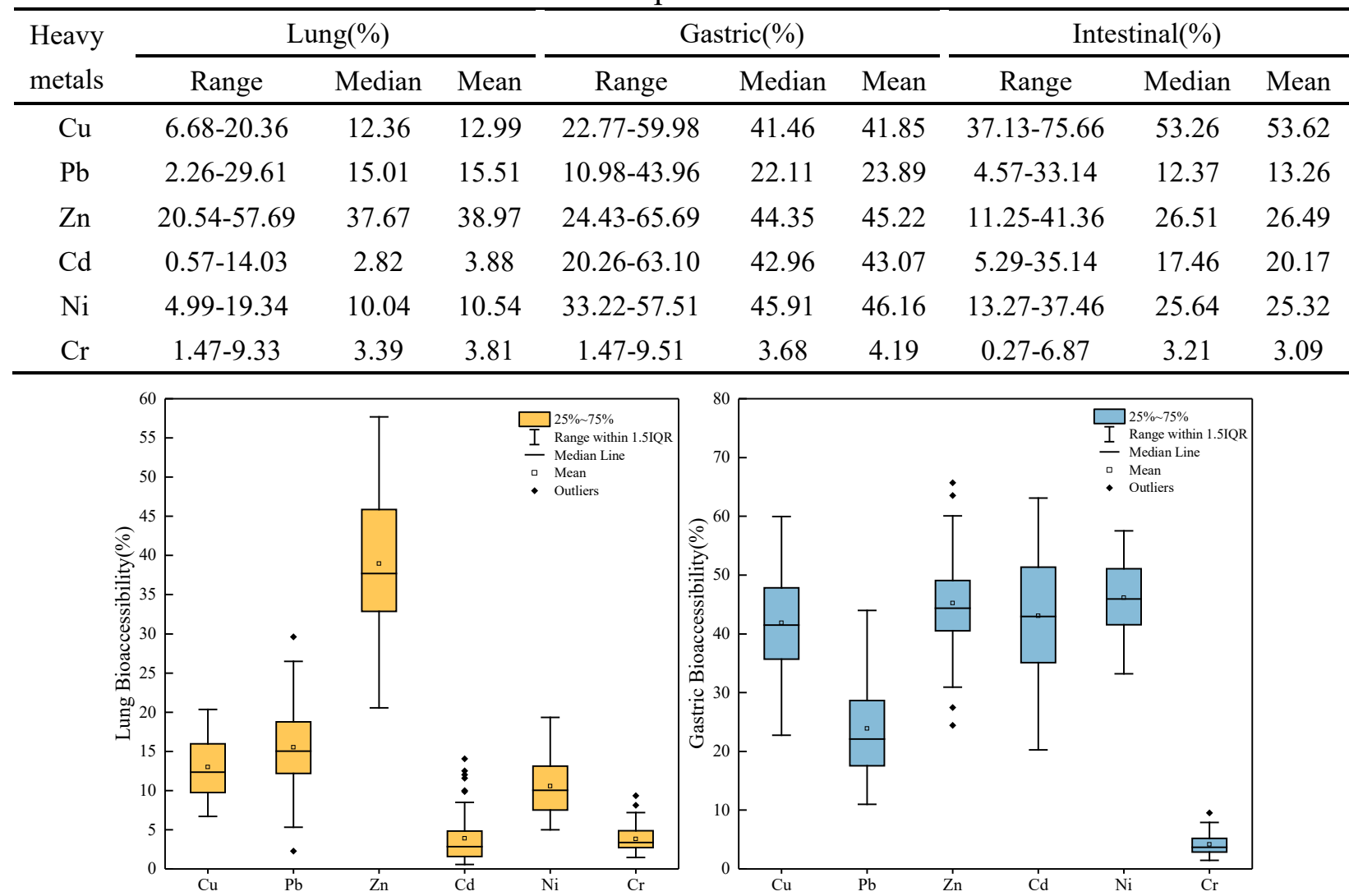




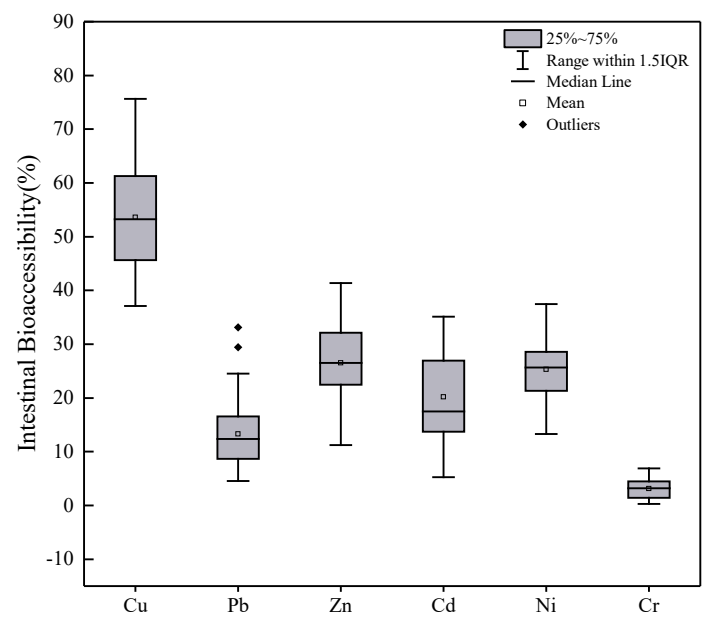

Figure 3. The percentage for bioaccessibility of each heavy metal at different simulation stages

\section{Relationships between the bioaccessibility and the total concentrations}

The linear relationships between total $\mathrm{Cu}, \mathrm{Pb}, \mathrm{Zn}, \mathrm{Cd}, \mathrm{Ni}$, and $\mathrm{Cr}$ in dust and bioaccessibility in the simulated lung phase, gastric phase, intestinal phase were presented in Figure 3, Figure 4, Figure 5. Linear coefficients $\left(\mathrm{R}^{2}\right)$ of the total amount of each heavy metal in the dust and bioaccessibility in the simulated lung phase were $0.0076,0.8137,0.8044,0.0367,0.0201$, and 0.0269 , respectively, and only the total amount for $\mathrm{Pb}\left(\mathrm{R}^{2}=0.8137\right)$ and $\mathrm{Zn}\left(\mathrm{R}^{2}=0.8044\right)$ showed a significant correlation with the concentration for the lung extraction stage, while other heavy metals had no significant linear relationship with total concentration. The linear coefficients $\left(\mathrm{R}^{2}\right)$ of each heavy metal in the gastric phase were $0.6057,0.8003,0.8074,0.6868,0.7151$, and 0.1168 , respectively, and the concentration of $\mathrm{Pb}, \mathrm{Zn}$, and $\mathrm{Ni}$ in the gastric extraction stage showed good correlations with the total amount in dust, while $\mathrm{Cu}$ and $\mathrm{Cd}$ showed moderate positive correlation, $\mathrm{Cr}$ had no significant correlation. The linear coefficients $\left(\mathrm{R}^{2}\right)$ of each heavy metal in the simulated intestinal phase were $0.6279,0.6276,0.5085$, $0.4501,0.4135$, and 0.1244 , respectively, and the total amount of heavy metals showed a moderate positive correlation with the concentration of the intestinal extraction stage except for Cr. It could be seen from the linear fit relationships in different phases that the total $\mathrm{Pb}$ and $\mathrm{Zn}$ were able to briefly assess the predicted digestive dissolution in the human lung and stomach, but most of the total heavy metals had no significant effect on their bioaccessibility. Since the human intake of heavy metals is mainly absorbed from the intestine, therefore, the previous health risk using total heavy metals had some errors and did not accurately reflect the absorption for heavy metals in the human body and carcinogenic and non-carcinogenic risk values (Sun et al. 2018).
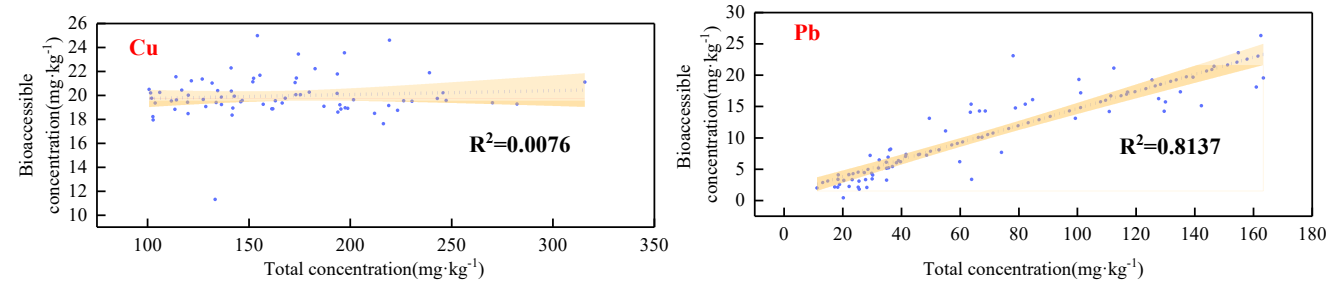

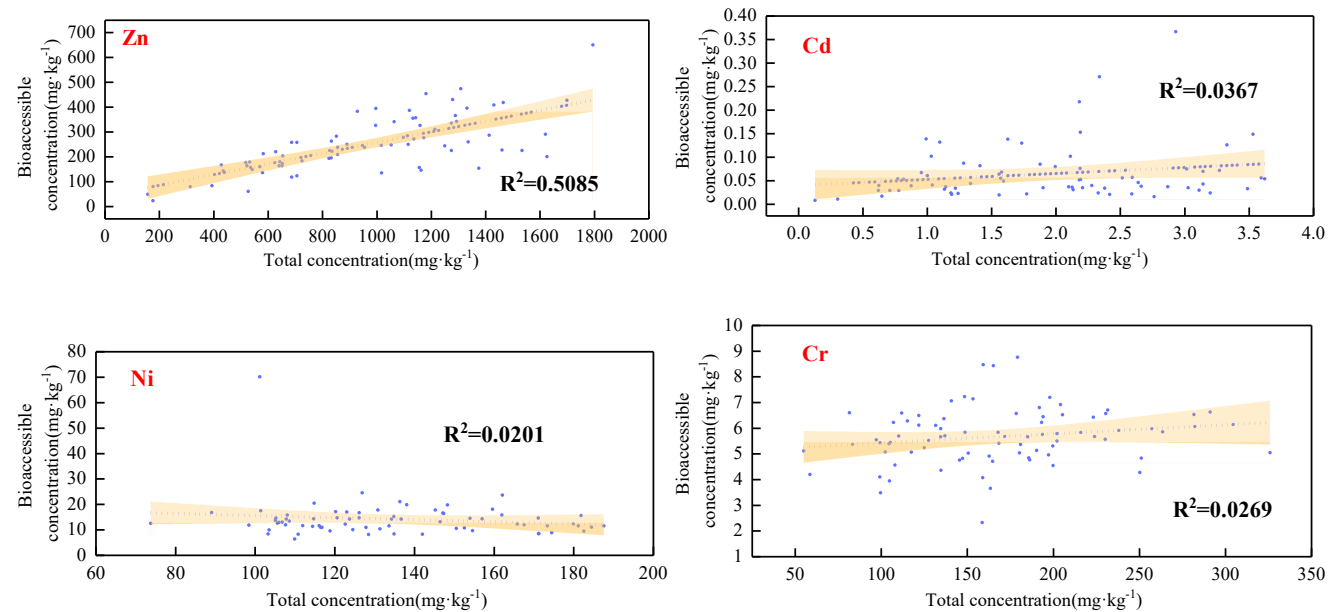

Figure 4. Linear fit of the lung phase
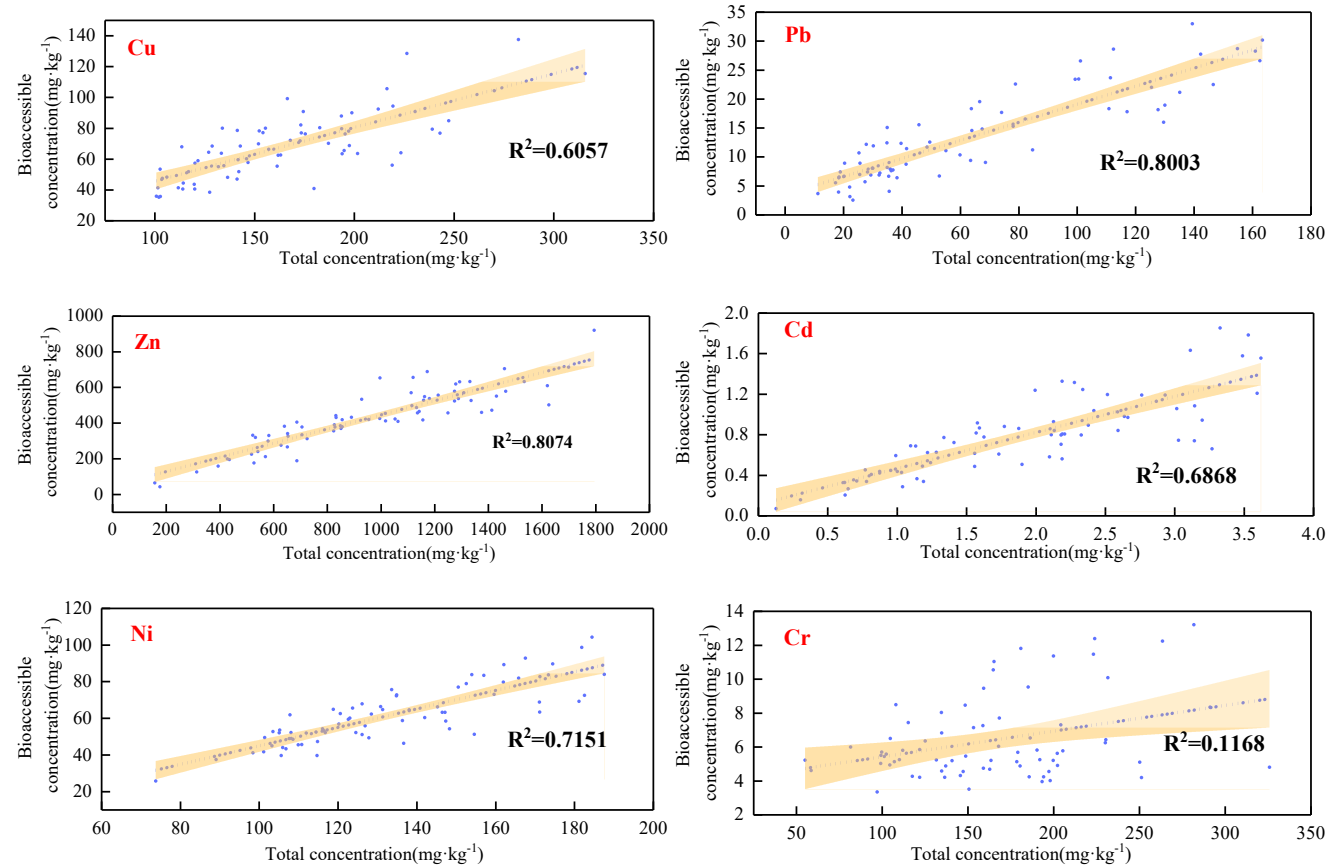

Figure 5. Linear fit of the gastric phase
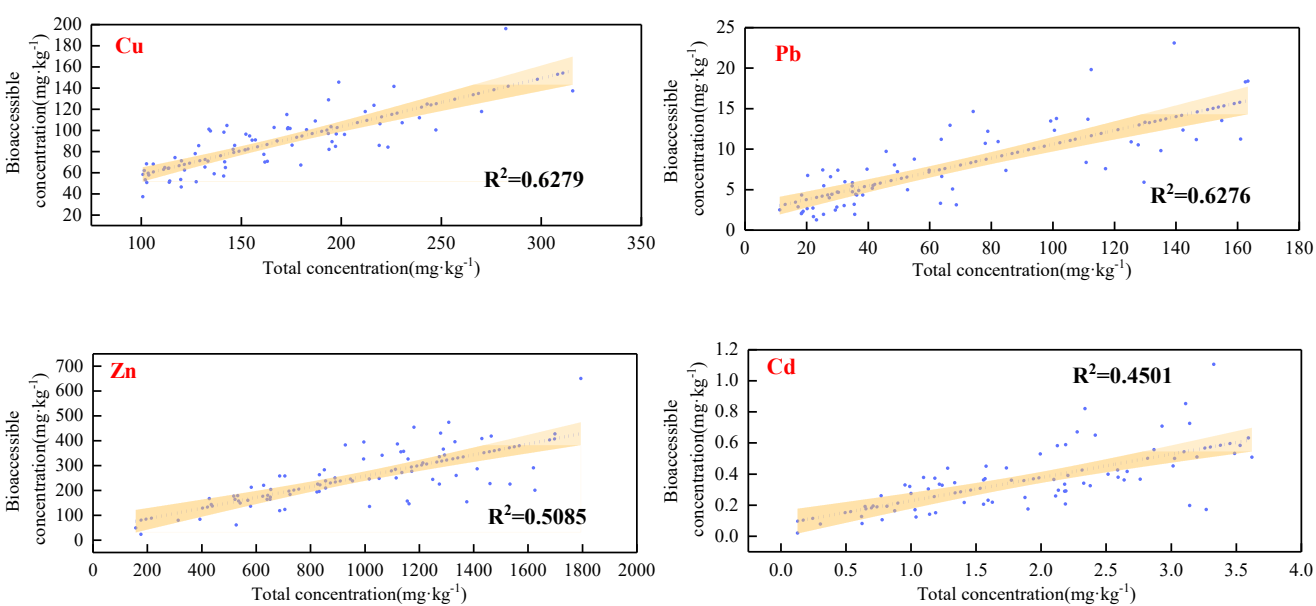

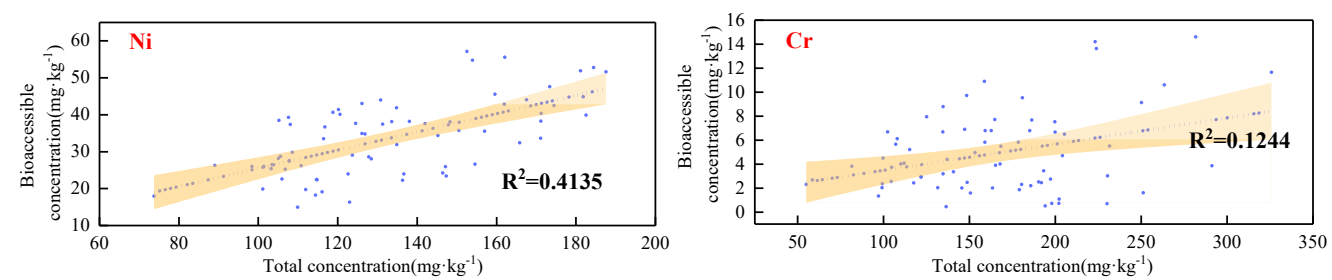

Figure 6. Linear fit of the intestinal phase

\section{Health risk assessment of heavy metals based on bioaccessibility}

Owing to heavy metals in the dust mainly entered the human body through two exposure pathways, respiratory inhalation, and hand-to-mouth ingestion, so the average daily exposure for these two exposure pathways was calculated using the simulated lung and simulated intestinal bioaccessibility instead of the total amount to avoid errors in risk evaluation results. According to Table 5, the average daily non-carcinogenic exposure for children was higher than that for adults in both pathways, and the average daily non-carcinogenic was also higher than that for adults, different heavy metals showed different bioaccessible concentrations in different stages, which led to different average daily non-carcinogenic and carcinogenic exposures for different heavy metals. The average daily exposure of non-carcinogenic heavy metals for hand-to-mouth intake was as follows: $\mathrm{Zn}>\mathrm{Cu}>\mathrm{Ni}>\mathrm{Pb}>\mathrm{Cr}>\mathrm{Cd}$, $\mathrm{Zn}$ was able to reach $8.29 \mathrm{E}-04$, and $\mathrm{Cd}$ the smallest was 1.21E-06. Compared with the average daily exposure by respiratory inhalation, each heavy metal also showed the same pattern, but the exposure was much smaller than hand-oral intake. Thus, it could be seen by comparison that the number of heavy metals absorbed in the intestine was higher, and the non-carcinogenic risk by hand-oral intake was also much higher than that by respiratory inhalation (Shahab et al. 2018). However, the non-carcinogenic risks for $\mathrm{Cu}, \mathrm{Pb}, \mathrm{Zn}, \mathrm{Cd}, \mathrm{Ni}$, and $\mathrm{Cr}$ in both exposure pathways did not exceed 1 , which were below the risk threshold, indicating that they did not have non-carcinogenic risks. Although the daily average exposure of $\mathrm{Zn}$ to children and adults was the highest under these two pathways, $\mathrm{Pb}$ was the noncarcinogenic element with the highest risk value in the non-carcinogenic risk assessment results. As for the three carcinogenic elements, $\mathrm{Cd}, \mathrm{Cr}$, and $\mathrm{Ni}$, basing the Table 3 that children had the highest average daily exposure of 4.99E-10 for Ni under the respiratory inhalation pathway, the total carcinogenic risk for children under the two pathways were $6.38 \mathrm{E}-07$, and the total carcinogenic risk value for adults was $8.71 \mathrm{E}-10$, while the carcinogenic risk values of $\mathrm{Cd}, \mathrm{Ni}$ and $\mathrm{Cr}$ for children were 6.35E-07, 1.40E10 and 2.76E-09, respectively, and it was known from the calculation results that cancer risk in adults was also negligible. According to the carcinogenic risk standard formulated by USEPA, we saw that the carcinogenic risk of children under these three elements was negligible, while the carcinogenic risk values of $\mathrm{Cd}, \mathrm{Ni}$, and $\mathrm{Cr}$ in adults are $1.46 \mathrm{E}-11,4.19 \mathrm{E}-10$ and $8.28 \mathrm{E}-09$ respectively, which the risk of cancer in adults was negligible from the calculation results. Seeing the evaluation results, we could find that although the non-carcinogenic and carcinogenic risks did not reach the risk values, the exposure to heavy metals was highest under the hand-to-mouth pathway of ingestion, so people who need to travel should take protective measures such as wearing 
a mask and washing hands regularly.

Table 5 Health risk assessment of heavy metals based on bioaccessibility in dust for adults and children.

\begin{tabular}{|c|c|c|c|c|c|c|c|c|c|c|}
\hline \multirow{2}{*}{$\begin{array}{l}\text { Heavy } \\
\text { metals }\end{array}$} & \multicolumn{5}{|c|}{ Children } & \multicolumn{5}{|c|}{ Adults } \\
\hline & $\mathrm{ADD}_{\text {ing }}$ & $\mathrm{HQ}_{\text {ing }}$ & $\mathrm{ADD}_{\text {inh }}$ & $\mathrm{HQ}_{\text {inh }}$ & $\mathrm{HI}$ & $\mathrm{ADD}_{\text {ing }}$ & $\mathrm{HQ}_{\text {ing }}$ & $\mathrm{ADD}_{\text {inh }}$ & $\mathrm{HQ}_{\text {inh }}$ & $\mathrm{HI}$ \\
\hline \multicolumn{11}{|c|}{ Hazard quotient(HQ) $/ \mathrm{mg} \cdot \mathrm{kg}^{-1} \cdot \mathrm{d}^{-1}$} \\
\hline $\mathrm{Cu}$ & $1.48 \mathrm{E}-04$ & $3.69 \mathrm{E}-03$ & $2.72 \mathrm{E}-09$ & $6.80 \mathrm{E}-08$ & $3.69 \mathrm{E}-03$ & $7.51 \mathrm{E}-05$ & $1.88 \mathrm{E}-03$ & 2.04E-09 & $5.09 \mathrm{E}-08$ & $1.88 \mathrm{E}-03$ \\
\hline $\mathrm{Pb}$ & $2.51 \mathrm{E}-05$ & $7.15 \mathrm{E}-03$ & $1.34 \mathrm{E}-09$ & 3.84E-07 & $7.15 \mathrm{E}-03$ & $1.27 \mathrm{E}-05$ & $3.64 \mathrm{E}-03$ & $1.01 \mathrm{E}-09$ & $2.88 \mathrm{E}-07$ & $3.64 \mathrm{E}-03$ \\
\hline $\mathrm{Zn}$ & $8.29 \mathrm{E}-04$ & $2.76 \mathrm{E}-03$ & $5.29 \mathrm{E}-08$ & $1.76 \mathrm{E}-07$ & $2.76 \mathrm{E}-03$ & $4.22 \mathrm{E}-04$ & $1.41 \mathrm{E}-03$ & $3.96 \mathrm{E}-08$ & $1.32 \mathrm{E}-07$ & $1.41 \mathrm{E}-03$ \\
\hline $\mathrm{Cd}$ & $1.21 \mathrm{E}-06$ & $1.22 \mathrm{E}-03$ & $8.77 \mathrm{E}-12$ & 8.77E-09 & $1.22 \mathrm{E}-03$ & $6.17 \mathrm{E}-07$ & $6.18 \mathrm{E}-04$ & $6.57 \mathrm{E}-12$ & $6.57 \mathrm{E}-09$ & $6.18 \mathrm{E}-04$ \\
\hline $\mathrm{Ni}$ & $1.12 \mathrm{E}-04$ & $5.58 \mathrm{E}-03$ & $1.94 \mathrm{E}-09$ & $9.43 \mathrm{E}-08$ & $5.58 \mathrm{E}-03$ & $5.67 \mathrm{E}-05$ & $2.84 \mathrm{E}-03$ & $1.46 \mathrm{E}-09$ & 7.07E-08 & $2.84 \mathrm{E}-03$ \\
\hline $\mathrm{Cr}$ & $1.62 \mathrm{E}-05$ & $5.41 \mathrm{E}-03$ & $7.68 \mathrm{E}-10$ & $2.68 \mathrm{E}-05$ & $5.44 \mathrm{E}-03$ & $8.25 \mathrm{E}-06$ & $2.75 \mathrm{E}-03$ & $5.75 \mathrm{E}-10$ & $2.01 \mathrm{E}-05$ & $2.77 \mathrm{E}-03$ \\
\hline Total & $1.13 \mathrm{E}-03$ & $2.58 \mathrm{E}-02$ & 5.97E-08 & $2.75 \mathrm{E}-05$ & $2.58 \mathrm{E}-02$ & $5.75 \mathrm{E}-04$ & $1.31 \mathrm{E}-02$ & 4.47E-08 & $2.06 \mathrm{E}-05$ & $1.32 \mathrm{E}-02$ \\
\hline \multicolumn{11}{|c|}{ Cancer risk $(\mathrm{CR}) / \mathrm{mg} \cdot \mathrm{kg}^{-1} \cdot \mathrm{d}^{-1}$} \\
\hline $\mathrm{Cd}$ & $1.04 \mathrm{E}-07$ & $6.35 \mathrm{E}-07$ & $7.52 \mathrm{E}-13$ & $4.74 \mathrm{E}-12$ & $6.35 \mathrm{E}-07$ & $6.01 \mathrm{E}-14$ & $3.67 \mathrm{E}-13$ & $2.25 \mathrm{E}-12$ & $1.42 \mathrm{E}-11$ & $1.46 \mathrm{E}-11$ \\
\hline $\mathrm{Ni}$ & - & - & $1.67 \mathrm{E}-10$ & $1.40 \mathrm{E}-10$ & $1.40 \mathrm{E}-10$ & - & - & $4.99 \mathrm{E}-10$ & $4.19 \mathrm{E}-10$ & $4.19 \mathrm{E}-10$ \\
\hline $\mathrm{Cr}$ & - & - & $6.58 \mathrm{E}-11$ & $2.76 \mathrm{E}-09$ & $2.76 \mathrm{E}-09$ & - & - & $1.97 \mathrm{E}-10$ & $8.28 \mathrm{E}-09$ & $8.28 \mathrm{E}-09$ \\
\hline Total & $1.04 \mathrm{E}-07$ & $6.35 \mathrm{E}-07$ & 2.34E-10 & 2.90E-09 & $6.38 \mathrm{E}-07$ & $6.01 \mathrm{E}-14$ & $3.67 \mathrm{E}-13$ & $6.98 \mathrm{E}-10$ & $8.71 \mathrm{E}-09$ & $8.71 \mathrm{E}-09$ \\
\hline
\end{tabular}

\section{Conclusion}

In this study, the total amount for $\mathrm{Cu}, \mathrm{Pb}, \mathrm{Zn}, \mathrm{Cd}, \mathrm{Ni}$, and $\mathrm{Cr}$ in surface dust in the old urban areas of Guiyang city, including recreational squares, main streets, hospitals, residential areas, and schools, were investigated in terms of their bioaccessibility in different simulated stages and health risk assessment in both respiratory inhalation and hand-to-mouth ingestion exposure pathways. The results indicated that : (1) The total amounts of $\mathrm{Cu}, \mathrm{Pb}, \mathrm{Zn}, \mathrm{Cd}, \mathrm{Ni}$, and $\mathrm{Cr}$ in surface dust in the old urban area of Guiyang exceeded the background values of Guizhou Province and showing different degrees of pollution, especially the extent of $\mathrm{Zn}$ exceeded was more serious, which was 9.71 times of the background value. The coefficient of variation indicated that $\mathrm{Pb}, \mathrm{Zn}$, and $\mathrm{Cd}$ were mainly disturbed by human activities and external factors. (2) Subsequently, bioaccessibility experiments of heavy metals in dust were conducted in the simulated lung, gastric, and intestinal, the results showed that heavy metals with the highest dissolution in the simulated lung stage, the highest bioaccessibility was Zn (38.97\%) and the lowest dissolution was $\mathrm{Cr}(3.81 \%)$. In the gastric phase, the highest bioaccessibility was $\mathrm{Ni}(46.16 \%)$ and the lowest dissolution was $\mathrm{Cr}(4.19 \%)$. In the intestinal phase, the highest bioaccessibility was $\mathrm{Cu}(53.62 \%)$ and the lowest dissolution was $\mathrm{Cr}$ (3.09\%). (3) Thirdly, a linear fit was performed between the total amount for heavy metals in dust and the bioaccessible amount of $\mathrm{Pb}$ and $\mathrm{Zn}$ in different simulation stages, finding that there was only the bioavailability of $\mathrm{Pb}$ and $\mathrm{Zn}$ appearing a better correlation with the total amount in the simulated lung and gastric phases. In the simulated intestine stage, the heavy metals involved in this study had no significant correlation with the total amount, it showed that the total amount of heavy metals alone cannot predict the human intake of heavy metals in the dust. (4) The results of health risk assessment based on bioaccessibility showed that the non-carcinogenic and 
carcinogenic risks for children were higher than those of adults under both hand-tomouth intake and respiratory inhalation exposure pathways, and the non-carcinogenic and carcinogenic risk values for $\mathrm{Cu}, \mathrm{Pb}, \mathrm{Zn}, \mathrm{Cd}, \mathrm{Ni}$, and $\mathrm{Cr}$ did not exceed the limits, indicating that the health risks of children and adults in this region were within acceptable limits, although the non-carcinogenic and carcinogenic risks did not reach risk values, the risk under the hand-to-mouth pathway was higher than those under the respiratory inhalation pathway so that people living in this urban area need to take certain protective measures. This research suggested that an assessment of the quality of the urban environment is necessary for more rational risk management of heavy metals in the city.

\section{Funding}

This research was supported by the National Natural Science Foundation of China (grant no. 41807336) and the Science and Technology Plan Project of Guizhou (grant no. [2019]1231).

\section{Ethical Approval}

Not applicable

\section{Consent to Participate}

Not applicable

\section{Consent to Publish}

Not applicable

\section{Authors Contributions}

Yu Xinjie conceived the research as the first author;Wang Ji , Cai Xiongfei and Zhang

Shuai participated in the guidance of the paper; Li Ding verified the correctness of the theoretical analysis and guided the smooth progress of the experiment;Zhao Shuai and

$\mathrm{Xu}$ Die measured the content of heavy metals in dust and operated in vitro simulation experiment.

\section{Competing Interests}

Not applicable

\section{Availability of data and materials}

Data available 


\section{References}

Li, Y. B., Fang, F. M., Lin, Y. S., Wang, Y., Kuang Y., Wu, M. H. (2019). Heavy metal contamination and health risks of indoor dust around Xinqiao Mining Area, Tongling, China. Hum Ecol Risk Assess 26:46-56. doi: 10.1080/10807039.2018.1503930.

Tang, Z., Miao, C., Cheng, J., Jing, J., and Li, Y. (2017). Contamination and Health Risks of Heavy Metals in Street Dust from a Coalmining City in Eastern China. Ecotox Environ Safe 138:83-91. doi: 10.1016/j.ecoenv.2016.11.003.

Damian, B. G., Nicholas, J. P., Kirstie, A. F.. (2007). Post-rehabilitation environmental hazard of $\mathrm{Cu}, \mathrm{Zn}, \mathrm{As}$ and $\mathrm{Pb}$ at the derelict Conrad Mine, eastern Australia. Environ Pollut 148:491-500. doi: 10.1016/j.envpol.2006.12.016.

Balamuralikrishnan, B., Meyyazhagan, A., Chinnappan, A. J., Alagamuthu, K. K., Arasu, M. V. (2020). Occupational health hazards on workers exposure to lead (Pb): A genotoxicity analysis. J Infect Public Heal 13: 527-531. doi: 10.1016/j.jiph.2019.10.005. Till J. J. H., King, M. L., Mendes, I., Lebreiro S., Lobo F. J., Oberle F. K., Anton, L., Ferreira, P. A., Reguera, M. I. (2018). Hazard potential of widespread but hidden historic offshore heavy metal ( $\mathrm{Pb}, \mathrm{Zn}$ ) contamination (Gulf of Cadiz, Spain). Sci Total Environ 637-638: 561-576. doi:10.1016/j.scitotenv.2018.04.352.

Kobra, N., Salmani, F., Zeinali, M., Zeinali, T.(2021). Health risk assessment of Cd, Cr, $\mathrm{Cu}, \mathrm{Ni}$ and $\mathrm{Pb}$ in the muscle, liver and gizzard of hen's marketed in East of Iran. Toxicol Rep 8:53-59. doi: 10.1016/j.toxrep.2020.12.012.

Michael, D. D., Thorn, R., Lau, W., Vasiluk, L., Hale, B. (2021). Gastric bioaccessibility is a conservative measure of nickel bioavailability after oral exposure: Evidence from Ni-contaminated soil, pure Ni substances and Ni alloys. Environ Pollut 268:115830. doi: 10.1016/j.envpol.2020.115830.

Nancy, Q., D. Zanabria, E. Chavez, F. Cuadros, and B. Paredes. (2021). Health risk assessment of heavy metals $(\mathrm{Hg}, \mathrm{Pb}, \mathrm{Cd}, \mathrm{Cr}$ and $\mathrm{As})$ via consumption of vegetables cultured in agricultural sites in Arequipa, Peru. Chemical Data Collections 33:100723. doi: 10.1016/j.cdc.2021.100723.

Renata, M. N., A. M. G. Figueiredo, C. E. S. Oliveira, and M. Babinski. (2021). Urban contamination sources in tunnel dusts from So Paulo city: Elemental and isotopic characterization. Atmos Environ 254:118188. doi: 10.1016/j.atmosenv.2021.118188.

Han, Q., M. Wang, J. Cao, C. Gui, and Y. Liu. (2020). Health risk assessment and bioaccessibilities of heavy metals for children in soil and dust from urban parks and schools of Jiaozuo, China. Ecotox Environ Safe 191:110157. doi: 10.1016/j.ecoenv.2019.110157.

Yu, B., X. W. Lu, X. Y. Fan, P. Fan, L. Zuo, Y. F. Yang, and L. Q. Wang. (2021). Analyzing environmental risk, source and spatial distribution of potentially toxic elements in dust of residential area in Xi'an urban area, China. Ecotox Environ Safe 208:111679. doi: 10.1016/j.ecoenv.2020.111679.

Jose, J., B. Srimuruganandam. (2021). Application of micro-morphology in the physical characterization of urban road dust. Particuology 54:146-155. doi: 10.1016/j.partic.2020.05.002.

Expósito, A., B. Markiv, L. R. Azcona, M. Santibaez, and I. F. Olmo. (2021). 
Understanding how methodological aspects affect the release of trace metal (loids)s from urban dust in inhalation bioaccessibility tests. Chemosphere 267:129181. doi: 10.1016/j.chemosphere.2020.129181.

Yin, N. Y., Y. L. Zhao, P. F. Wang, H. L. Du, M. Yang, Z. L. Han, X. C. Chen, G. X. Sun, and Y. S. Cui. (2021). Effect of gut microbiota on in vitro bioaccessibility of heavy matal and human health risk assessment from ingestion of contaminated soils. Environ Pollut 279:116943. doi: 10.1016/j.envpol.2021.116943

Du, H. L., N. Y. Yin, X. L. Cai, P. F. Wang, Y. Li, Y. Q. Fu. (2020). Lead bioaccessibility in farming and mining soils: The influence of soil properties, types and human gut microbiota. Sci Total Environ 708:135227. doi: 10.1016/j.scitotenv.2019.135227.

Sultana, M. S., P. F. Wang, N.Y. Yin, M. H. Rahman, H. L. Du, X. L. Cai, Y. Q. Fu, and Y. S. Cui. (2020). Assessment of nutrients' effect on the bioaccessibility of $\mathrm{Cd}$ and $\mathrm{Cu}$ in contaminated soil. Ecotox Environ Safe 202:110913. doi: 10.1016/j.ecoenv.2020.110913.

Khelifi, F., A. G. Caporale, Y.Hamed, and P. Adamo. (2021). Bioaccessibility of potentially toxic metals in soil, sediments and tailings from a north Africa phosphatemining area: Insight into human health risk assessment. J Environ Manage 279:111634. doi: 10.1016/j.jenvman.2020.111634.

Zoitos, B. K., Meringo A, Rouyer E, et al.(1997). In vitro measurement of fiber dissolution rate relevant to biopersistence at neutral $\mathrm{pH}$ : An interlaboratory round robin. Inhal Toxicol 9(6): 525-540.

Ruby, M. V., A. Davis, T. E. Link, R. Schoof, R. L. Chaney, G. B. Freeman, and P, Bergstrom. (1993). Development of an in vitro screening test to evaluate the in vivo bioaccessibility of ingested mine-waste lead. Environ Sci Technol 27:2870-2877. doi: 10.1021/es00049a030.

Ruby, M. V., R. Schoof, W. Brattin, M. Goldade, G. Post, M. Harnois, D. E. Mosby, S. W. Casteel, W. Berti, and M. Carpenter. (1999). Advances in evaluating the oral bioavailability of inorganics in soil for use in human health risk assessment. Environ Sci Technol 33(21):3697-3705. doi: 10.1021/es990479z.

USEPA. (1989). Risk assessment guidance for superfund (volume I) human health evaluation manual, pp.1-89. Office of Soild Waste and Emergency Response, US Environmental Protection Agency, Washington, DC, USA.

USEPA. (2001). Supplemental guidance for developing soil screening levels for superfund sites. OSWER 9355.4-24. Office of Solid Waste and Emergency Response, Washington, DC.

USEPA. (2007). Guidance for Evaluating the Oral Bioavailability of Metals in Soils for Use in Human Health Risk Assessment. OSWER 9285.7-80. Office of Solid Waste and Emergency Response, Washington, DC.

USEPA. (2008). Standard Operating Procedure for an in Vitro Bioaccessibility Assay for Lead in Soil. EPA 9200.1-86.

Duan XL, Huang N, Wang BB. (2012). Development of Exposure Factors Research Methods in Environmental Health Risk Assessment. J Environ Health 29(2):99-104. (in chinese)

USEPA. (2011). User's Guide and Background Technical Document for USEPA Region 
9's Preliminary Remediation Goals (PRG) Table.

Xiao, Q., Y. T. Zong, M. Zaffar, and S. G. Lu. (2020). Source identification and risk assessment of heavy metals in road dust of steel industrial city (Anshan), Liaoning, Northeast China. Hum Ecol Risk Assess 26: 1359-1378. doi: 10.1080/10807039.2019.1578946

Zheng, N., S. Hou, S. Wang, S. Sun, and X. Li. (2020). Health risk assessment of heavy metals in street dust around a zinc smelting plant in China based on bioavailability and bioaccessibility. Ecotox Environ Safe 197: 110617. doi: 10.1016/j.ecoenv.2020.110617. Goix, S., G. Uzu, P. Oliva, F. Barraza, A. Calas, S. Castet, D. Point, J. Masbou, J. L. Duprey, and C. Huayta. (2016). Metal concentration and bioaccessibility in different particle sizes of dust and aerosols to refine metal exposure assessment. J Hazard Mater 317:552-562. doi: 10.1016/j.jhazmat.2016.05.083.

Fan, X. Y., X. W. Lu, H. M. Liu. (2020). Pollution and Source Analysis of Heavy metals in Surface Dust from Xian University Campuses. Environ Sci 41(08):3556-3562. (in chinese)

Adachi K, Tainoshu Y. (2004). Characterization of heavy metals particles embedded in tire dust. Environ Int 30(8): 1009-1017.

Li, L., W. Xing, Q. Zhao, K. G. Scheckel, and L. Zheng. (2019). Inhalation bioaccessibility of $\mathrm{cd}, \mathrm{cu}, \mathrm{pb}$ and $\mathrm{zn}$ and speciation of $\mathrm{pb}$ in particulate matter fractions from areas with different pollution characteristics in henan province, China. Ecotox Environ Safe 175: 192-200. doi: 10.1016/j.ecoenv.2019.03.062.

Zhang, M., X. Li, R. Yang, J. Wang, Y. Ai, Y. Gao, Y. Zhang, X. Zhang, X.Yan, and B. Liu. (2019). Multipotential toxic metals accumulated in urban soil and street dust from Xining city, NW China: spatial occurrences, Sources, and Health risks. Arch Environ Contam Toxicol 76(2): 308-330. doi: 10.1007/s00244-018-00592-8.

Soltani, N., B. Keshavarzi, F. Moore, M. Cave, and R. Golshani. (2021). In vitro bioaccessibility, phase partitioning, and health risk of potentially toxic elements in dust of an iron mining and industrial complex. Ecotox Environ Safe 212: 111972. doi: 10.1016/j.ecoenv.2021.111972.

Zhao, L. S., R. L. Yu, Y.Yan, Y. Cheng, and H. Huang. (2020). Bioaccessibility and provenance of heavy metals in the park dust in a coastal city of southeast China. Appl Geochem 123: 104798. doi: 10.1016/j.apgeochem.2020.104798.

Xu, L.L., L. Jiao, Z. Y. Hong, Y. R. Zhang, W. J. Du, X. Wu, Y. T. Chen, J. J. Deng, Y. W. Hong, and J. S. Chen. (2018). Source identification of PM2.5 at a port and an adjacent urban site in a coastal city of China: impact of ship emissions and port activities. Sci Total Environ 634: 1205-1213. doi: 10.1016/j.scitotenv.2018.04.087.

Sun, L. Q., C. Y. Sun, F. Liu, and X. M. Bao. (2018). Health risk assessment of oral bioaccessibility of heavy metal in soil from coalfield in Huaibei City, China. Hum Ecol Risk Assess 25: 2045-2055. doi: 10.1080/10807039.2018.1485480.

Shahab, A. D., K. Mahin, A. Majid, and Y. Mojgan. (2018). Pollution and health risk assessment of heavy metals in agricultural soil, atmospheric dust and major food crops in Kermanshah province, Iran. Ecotox Environ Safe 163: 153-164. doi: 10.1016/j.ecoenv.2018.07.057. 
